\title{
ANTIBACTERIAL EFFECT OF LIGHT-ACTIVATED CALCIUM SILICATE VERSUS CALCIUM HYDROXIDE ON PERMANENT CARIOUS MOLARS TREATED WITH STEP-WISE EXCAVATION: A RANDOMIZED CLINICAL TRIAL
}

\author{
Hanaa Mohamed Morsy*, Omaima Mohamed Safwat**, \\ Mohsen Hussien Abi Elhassan** and Marwa Kamal Mohamed ${ }^{* * *}$
}

\begin{abstract}
Aims and Objectives: to evaluate the antibacterial action of Theracal (light-cured calcium silicate) liner in comparison to Biner LC (light-cured calcium hydroxide) liner on permanent carious molars treated with step-wise excavation in 6 months follow-up.

Materials and Methods: A total of 48 patients were assigned in this study. Participants were divided into two groups randomly according to the type of liner that was placed and sample of dentin that will be taken before placement of liner and after placement ( 6 months). Application of both materials was done according to the manufacturers ' instructions after the excavation of caries on the cavity walls and dentin sample was taken from the central carious lesion for microbiological analysis, then the cavities were sealed with conventional glass ionomer cement as a temporary restoration. After 6 months, the cavities were reopened, temporary restorations and pulp capping material were removed, and second dentin sample was taken for microbiological analysis. Caries was excavated to firm dentin and teeth were restored with permanent resin composite restorations. Agar Diffusion test and Digital Colony Counter were conducted for the study. The measuring unit of the bacterial count was CFU/ml.
\end{abstract}

Results: There was no statistically significant difference between the two groups for Streptococcus Mutants and Lactobacillus Bacterial count after 6 months.

Conclusion: 1- Antibacterial activity of the resin-modified calcium silicate has nearly the same effect as the light-cured Calcium Hydroxide, however still doubtful to be used as the gold standard for pulp capping material. 2- Regardless the pulp capping material used, avoiding bacterial contamination and marginal sealing is essential in preserving the tooth vitality with deep Class I carious lesions.

KEYWORDS: Dental Caries, Calcium Hydroxide, Calcium Silicate, Step-wise Excavation, Bacterial Count.

\footnotetext{
* Master Degree Operative Department, Faculty of Dentistry, Cairo University,

** Department of Conservative Dentistry, Faculty of Dentistry, Cairo University, \& October 6 University, Cairo, Egypt. *** Department of Microbiology and Immunology, Faculty of Medicine, Cairo University, Cairo, Egypt
} 


\section{INTRODUCTION}

Despite advancements in caries prevention and early detection, untreated caries remains the most common disease worldwide.$^{[1]}$ A recurrent challenge for clinicians may occur due to the shortcoming of early intervention which leads to the progression of early carious lesions to deep cavities involving the inner third of dentin. ${ }^{[2]}$ In deep carious lesion of tooth, the complete removal may lead to an accidental pulp exposure, to avoid this the stepwise technique is used, which consists of removing infected dentin leaving the affected dentin, clinically leaving part of soft dentin which is near to the pulp and apply a biomaterial to diminish the progression of the lesion or arrest it, temporary sealing for 1-6 months, subsequently reopening the cavity and fully removing the carious tissue followed by restoration. ${ }^{[3]}$ During the temporary sealing of the tooth, the remaining carious dentine becomes harder and drier, both characteristics of inactive lesions, and exhibit a low level of bacterial infection. ${ }^{[4]}$

However, there are concerns regarding the microorganisms that can be left behind without the risk of the caries progression and studies are yet to be made. Several microbiological studies had reported the persistence of bacteria in dentin in cavities treated by either partial caries removal or complete caries removal techniques. ${ }^{[5]}$ The biomaterial such as calcium hydroxide or calcium silicate manufactured to have an anti-bacterial effect on micro-organisms within the dentin, thus allowing the inhibition of bacterial growth therefore no caries will progress. ${ }^{[6]}$

Unfortunately, some cases of restored carious molars may relapse and the recurrence of caries on treated tooth may occur due to several factors. One of the factors might be the virulent action of the microrganisms within the dentin which outstanded the antibacterial effect of the biomaterial used. Some microbiological studies had reported the persistence of the bacteria in dentin in cavities treated by either partial caries removal or complete caries removal techniques.$^{[5]}$ Therefore the purpose of this study was to evaluate the antibacterial effect of lightactivated Calcium Silicate (Theracal) versus lightcured calcium hydroxide on permanent carious molars treated with Step-wise Excavation.

\section{MATERIALS AND METHODS}

\section{Study setting}

This randomized clinical study was conducted on adult patients attending to the operative clinic in The Faculty of Oral and Dental Medicine, Cairo University, Egypt. Protocol of this study was registered in www.clinicaltrials.gov/database, with unique identification number NCT03214770. The procedures was carried out by postgraduate student Hanaa Mohamed Morsy [B.D.S. 2011 from Misr University for Science and Technology] without an assistant.

\section{Sample size calculation}

The aim of this study is to evaluate the antibacterial action of TheraCal (light-cured Calcium Silicate base/liner), comparing this material with Calcium Hydroxide paste. If the expected clinical differences in bacterial count by digital colony counter, agar diffusion test is $1 \pm 1$. Using power $80 \%$ and $5 \%$ significance level, we will need to study 17 in each group to be able to reject the null hypothesis that the population means of the experimental and control groups are equal. This number is to be increase to 24 in each group to compensate for possible losses during follow up according to Petrou et al., 2014. ${ }^{[7]}$ The sample size was calculated by PS program.

\section{Materials}

The pulp capping materials are as follows:

1. Light-cured calcium hydroxide "Biner LC" (Comparator)

2. Resin-modified light-cured calcium silicate "TheraCal" (Intervention) 
Temporary restorative material: Auto-cured Patients Recruitment

Glass Ionomer "GC Fuji IX GP Fast"

Adhesive System consisted of 37\% Phosphoric Acid etchant Gel "Meta Etchant" and (3M ESPE)

Single Bond Universal adhesive

Resin composite material "Filtek ${ }^{\mathrm{TM}} \mathrm{Z} 250$ Universal Restorative" (3M ESPE) [Table 1].
Announcement to residents of outpatient clinic in Conservative Dentistry department- Faculty of Dentistry- Cairo University Egypt, to screen adult patient during diagnosis for their chief complain so patients with at least one carious teeth with no pulpal symptoms was enrolled in this study, if they met the eligibility criteria. The inclusion and exclusion criteria were given in Table 2.

TABLE (1) Materials' specifications, composition, Batch no. number and manufacturer

\begin{tabular}{|c|c|c|c|c|}
\hline Trade Name & Material & Composition & Manufacturer & Batch No. \\
\hline $\begin{array}{l}\text { Theracal } \\
\text { LC } ®\end{array}$ & $\begin{array}{l}\text { Light-cured Resin- } \\
\text { Modified Calcium } \\
\text { Silicate Pulp } \\
\text { Protectant/ Liner }\end{array}$ & $\begin{array}{l}\text { Portland Type III cement }(45 \%) \text {, fumed } \\
\text { silica as thickening agent }(7 \%) \text {, resin( }(43 \%) \text {, } \\
\text { bismuth oxide( } 3 \%) \text {, and barium } \\
\text { sulfate( } 3 \%) \text { as radiopaquers }\end{array}$ & $\begin{array}{l}\text { BISCO Inc. } \\
\text { (Schamburg, IL, USA) }\end{array}$ & 170003198 \\
\hline Biner LC $®$ & $\begin{array}{l}\text { Light-cured } \\
\text { Calcium } \\
\text { Hydroxide paste }\end{array}$ & $\begin{array}{l}\text { Hydroxy calcium phosphate, UDMA, } \\
\text { Photonitator, Barium aluminum silicate }\end{array}$ & $\begin{array}{l}\text { META BIOMED } \\
\text { CO.LTD } \\
\text { (Chungcheongbukdo, } \\
\text { Korea) }\end{array}$ & BLC1804161 \\
\hline $\begin{array}{l}\text { GC } \\
\text { FUJI IX } \\
\text { Capsules }\end{array}$ & $\begin{array}{l}\text { Resin-modified } \\
\text { Glass Ionomer }\end{array}$ & $\begin{array}{l}\text { Powder: Fluoro-alumino-silicate glass, } \\
\text { Polyacrylic acid powder, Pigment Liquid: } \\
\text { Polyacrylic acid, Distilled water, Polybasic } \\
\text { carboxylic acid }\end{array}$ & $\begin{array}{l}\text { GC CORPORATION } \\
\text { (Tokyo, Japan) }\end{array}$ & 1602092 \\
\hline $\begin{array}{l}\text { Meta } \\
\text { Etchant }\end{array}$ & $\begin{array}{l}37 \% \text { Phosphoric } \\
\text { Acid etchant Gel }\end{array}$ & $37 \%$ Phosphoric acid & $\begin{array}{l}\text { META BIOMED } \\
\text { CO.LTD } \\
\text { Chungcheongbuk, Korea }\end{array}$ & MET1811151 \\
\hline $\begin{array}{l}\text { 3M ESPE } \\
\text { Single Bond } \\
\text { Universal }\end{array}$ & $\begin{array}{l}\text { Single Bond } \\
\text { Universal } \\
\text { Adhesive }\end{array}$ & $\begin{array}{l}\text { MDP Phosphate Monomer, Dimethac- } \\
\text { rylate resins, HEMA, Vitrebond, } \\
\text { Copolymer, filler, ethanol, water, initiators, } \\
\text { silage }\end{array}$ & $\begin{array}{l}\text { 3M Deutschland } \\
\text { GmbH, } 41453 \text { Neuss, } \\
\text { Germany }\end{array}$ & 547837 \\
\hline $\begin{array}{l}\text { 3M } \\
\text { Filtek }^{\text {TM }} \\
\text { Z250 XT }\end{array}$ & $\begin{array}{l}\text { Nano-hybrid } \\
\text { Universal } \\
\text { Composite Resin }\end{array}$ & $\begin{array}{l}\text { bis-GMA, UDMA, TEGDMA, bisEMA(6) } \\
\text { resins. Fillers: non agglomerated/non- } \\
\text { aggregated } 20 \mathrm{~nm} \text { silica filler, } 4 \text { to } 11 \mathrm{~nm} \\
\text { zirconia filler, and aggregated zirconia/ } \\
\text { silica cluster filler (comprised of } 20 \mathrm{~nm} \\
\text { silica and } 4 \text { to } 11 \mathrm{~nm} \text { zirconia particles) }\end{array}$ & $\begin{array}{l}\text { 3M ESPE, Dental } \\
\text { Products ( } 2510 \text { Conway } \\
\text { Avenue St. Paul, MN, } \\
\text { USA) }\end{array}$ & N728093 \\
\hline
\end{tabular}


TABLE (2): Inclusion and Exclusion Criteria

\begin{tabular}{ll}
\hline Inclusion criteria & Exclusion Criteria \\
\hline $\begin{array}{l}\text { Normal adults were recruited in this study, all the volunteers } \\
\text { participated in this experiment were healthy looking with free } \\
\text { medical history. }\end{array}$ & $\begin{array}{l}\text { Subjects with a history of allergy to any of the drugs or } \\
\text { chemicals used in the study. } \\
\text { Subjects with carious anterior tooth were not within the } \\
\text { study. }\end{array}$ \\
$\begin{array}{l}\text { In each patient required one or two deep carious tooth occlusally } \\
\text { either upper or lower permanent molars. }\end{array}$ & $\begin{array}{l}\text { History of pulp pathology of the teeth which indicates root } \\
\text { canal treatment was not included in the study. }\end{array}$ \\
$\begin{array}{l}\text { All volunteers must be with good oral hygiene in order to restore } \\
\text { with composite restorations. }\end{array}$ & $\begin{array}{l}\text { Pregnancy and Lactating mothers. } \\
\text { Pubjects were required to be available for the duration of the with any systematic problems or mental or physical } \\
\text { study, and to sign an informed consent form. }\end{array}$ \\
\hline
\end{tabular}

\section{Allocation, sequence generation and blinding}

Randomization was conducted by computer software www.random.org. using Random Integer Generator. The sequence generated 2 codes (A and B). Sample size 24 in each group was compensated for possible losses during follow-up. It was a singleblinded study so that the participant were blinded, the researcher and the data analysis were un-blinded, due to the different restorative material application .

\section{Grouping of samples}

Each patient had one or two deep carious molars which fulfilled the inclusion criteria, resulting in a total of 48 carious molars. Forty eight eligible teeth was randomly divided into two groups $(n=24)$ according to the type of liner that will be placed. The first group (D1) represents dentin sample before and after treatment with light-cured Calcium Silicate $\{\mathrm{n}=48\}$, and (D2) represents the dentin sample before and after treatment with light-cured Calcium Hydroxide $\{n=48\}$. Both 2 groups where stored in a media and transferred to the microbiological lab immediately for analysis at the time baseline of the study (T1). Patients were recalled after 6 months for the re-entry of the restored teeth , removing the Glass Ionomer restoration and collected the dentin sample (T2).

\section{Ethical policy and institutional review board statement}

This randomized clinical study was conducted in Faculty of Dentistry, Cairo University Egypt. Protocol of the current study was registered in the database www.clinicaltrials.gov/ with unique identification number ID NCT03214770. This protocol and the template of informed consent form was reviewed by the Ethics Committee of scientific research, Faculty of Oral and Dental Medicine, Cairo University.

\section{Declaration of patient consent}

The authors certify that they have gathered all patient consent forms. In each of the patients form, they have given their consent for their images and other clinical information to be reported in the journal. The patient understand that their names and initials will not be published and due efforts will be made to conceal their identity, but anonymity cannot be guaranteed.

\section{Teeth Selection}

The lesions were classified using the International Caries Detection and Assessment System (ICDASII). After air-drying the teeth using triplex syringe ICDAS-II scores of the lesions was obtained. Eligible scores for this study were codes 4,5 and 
6.The chosen sites were recorded as: Code 4, when non-cavitated lesion extending into dentin seen as an undermining shadow; code 5, small cavitated lesion with visible dentin: less than $50 \%$ of surface; code 6 , large cavitated lesion with visible dentin: more than $50 \%$ of surface. In all cases, dentin lesions were soft and wet indicating an active lesion.

\section{Cavity Preparation}

Under local anesthesia (4\% Articane 1:100,000 Epinephrine, Septodont, France) and rubber dam isolation (Nictone, MDC dental, Zapopan, Jalisco, Mexico), a high-speed hand piece (NSK Pana Air, Japan) with water coolant, and No. \#245 bur (Komet dental Gebr brasseler GmbH\& Co lemgo, Germany [0.8 $\mathrm{mm}$ in diameter and $1.6 \mathrm{~mm}$ in length]) were used to remove the cavosurface margin allowing access to restricted carious lesion beyond dentinoenamel junction and obtaining outline form.

Complete caries excavation was performed in the cavityexcept at the cavity floor where partial caries removal was performed. The partial caries removal was performed using sharp sterile discoid excavator (DENTSPLY, maillefer). Carefully, the softer friable necrotic superficial carious dentin on the cavity floor was removed with the excavator without exerting pressure on floor of the cavity until a slightly moist and reasonably leathery dentin is reached and remained. After that the walls of the cavity were finished using no. \#245 bur followed by completion of finishing of enamel walls and margins prior the baseline (T1) dentin sampling.

\section{Baseline Dentin Sampling}

Using sharp, sterile excavator, scoops of the soft carious dentin was taken. The amount of dentin removed was sufficient enough to cover the surface of the excavator. However, the skin-like caries, which could be removed with an excavator, was left on the pulpal wall to prevent pulp exposure after excavation of the soft carious dentin. The dentin sample was placed in a plastic carrier filled with saline during work and then immediately transferred to sterile disposable test tube containing $1.5 \mathrm{ml}$ thioglycollate medium used as a carrier and kept in an ice box then taken to the microbiology laboratory for processing within two hours. After incubation for 48 hours microbial counts were performed by a microbiologist, who was unaware of the treatment of the patients. The number of bacteria obtained for a given amount of dentin was used to estimate the number of bacteria present in $1 \mathrm{mg}$ of dentin (CFU/mg). ${ }^{[8]}$

\section{Restorative Procedures of Time Baseline}

After the baseline dentin sampling, the cavity was indirectly pulp capped either with Theracal ${ }^{\circledR}$ (BISCO Inc. Schamburg, IL, USA) or Biner LC® (META BIOMED CO.LTD ,Chungcheongbukdo, Korea), according to the allocation the teeth was assigned to. Cavity was then sealed using the autocured Glass Ionomer GC FUJI IX ${ }^{\circledR}$, as a long-term temporary restoration. The FUJI IX capsules were pressed down till filling the entire cavity then excess material was removed and preliminary occlusal anatomy was formed using a ball burnisher. After 3 minutes, restoration was contoured using fine and flame diamond finishing stones under coolant, and then the occlusion was checked using fine carbon paper and adjusted. Patient was dismissed and assigned to another appointment after six months for the re-entry of the cavity for the post-intervention dentin sampling and final restoration procedures.

\section{Restorative Procedures after 6 months (T2)}

After the six month, patient was recalled for the re-entry appointment collecting the postintervention dentin sample followed by restoring the permanent restoration. Three teeth were droppedout at the second visit for re-entry, 2 samples were due to patients not responding and the third was due to pathological exposure. The cavity was re-entered with an inverted diamond stone (DIA-BURS \#S148 ) removing the temporary restoration till reaching 
the pulp capping material. With the aid of a caries detector dye (Seek- Ultradent, Product Inc.,USA), further excavation was applied to collect the postintervention dentin sample (T2) using the sharp sterile discoid excavator (DENTSPLY, maillefer), and removing the residual caries until reaching a hard and smooth pulpal floor resistant to excavation. After obtaining the post-intervention sample, selective enamel etching technique was followed with a $37 \%$ Phosphoric acid etching gel for 15 seconds. Then rinsed thoroughly with a vigorous stream of water for 5 seconds and dried with compressed air until the etched enamel surfaces appeared chalky white. The adhesive Scotchbond ${ }^{\circledR} 3 \mathrm{M}$ Universal bond was scrubbed into the tooth surface for 20 seconds. Then dispersed with oil- and moisturefree compressed air until a glossy, immobile film layer resulted and cured for 20 seconds by a LED-curing unit (Demi Ultra, Kerr Corp.,Orange, CA, USA). The restorative material nanohybrid universal composite (3M Filtek ${ }^{\mathrm{TM}}$ Z250 XT) was placed in increments by cusp building technique 2-mm thickness in each increment, adapted to the cavity walls with a suitable instrument and cured for 40 seconds. Occlusal adjustments were made using articulating paper and the final contouring and finishing of restorations were performed using finishing diamond burs, followed by polishing with composite polishing rubber cup. The clinical procedure of tooth preparation and placement of restorations were performed by the same operator.

\section{Microbiological Analysis}

The test tubes containing the dentin samples were shaken in a vortex for 30 seconds to disperse bacterial aggregates and successive decimal dilutions were then prepared in sterile saline $(0.9 \%$ $\mathrm{NaCl}$ ) for each sample. Using a micropipette, $50 \mu$ l of each dilution were transferred on the surface of the agar plates then spread using sterile glass rod to give homogenous bacterial growth. Mitis salivarius agar medium (HiMedia,India) was used for Streptococcus mutants count, while
Lactobacillus MRS agar (HiMedia, India) was used for Lactillobacilli count. The mitis salivarius agar plates were incubated in an atmosphere of $5 \% \mathrm{CO} 2$ inside a candle jar for 48 hours, whereas, Lactobacillus MRS agar plates were incubated under anaerobic conditions for 48 hours $/ 37^{\circ} \mathrm{C}$ with the usage of Anaerobic gas pack kits provided by (Oxoid,UK).After incubation, plates were evaluated to choose the one with suitable numbers able to be counted. The number of CFU/50 microns/sample was determined on plates containing average 10-300 colonies of SM and LB colonies in dentin sample in the suitable dilution, before and after application of intervention. ${ }^{[8]}$ Microbial counts were performed by a single examiner who was unaware of the treatment of the patients.

\section{Statistical Analysis}

Data was analyzed using IBM SPSS advanced statistics (Statistical Package for Social Sciences), version 21 for Windows (SPSS Inc., Chicago, IL). Numerical data was described as mean and standard deviation $( \pm \mathrm{SD})$, or median and range. Categorical data were described as numbers and percentages when appropriate. The data was explored for normality using Kolmogrov-Smirnov test and ShapiroWilk test. Comparisons between two groups for normally distributed numeric variables were done using the Student's t-test while for non-normal distributed numeric variables were done by MannWhitney test. Comparisons between categorical variables was performed using the chi square test. A p-value less than or equal to 0.05 was considered statistically significant. All tests were two tailed.

\section{RESULTS}

The mean and standard deviation values were calculated for each group in each test. To calculate the number of $\mathrm{CFU} / \mathrm{ml}$ in sample, the count brought from the plates were multiplied by 20 , to get the bacterial count in $1 \mathrm{ml}$, then multiplied by 10 or 100 according to the dilution used in counting. 


\section{The anti-bacterial effect of capping material on Streptococcus Mutants (S. Mutans)}

The effect of capping material on S. mutants was presented in the form of mean and standard deviation in (Table 3) and (Figure 1). There was a statistically significant difference between baseline (T1) and after 6months (T2) in both Theracal and Biner LC groups where $(\mathrm{p}<0.001)$. However between the two groups, bacterial count after 6 months (T2) shown in (Figure 1) presented no statistically significant difference between Group A (Theracal) and Group $\mathrm{B}$ (Biner LC) groups where $(\mathrm{p}=0.474)$. Regarding bacterial reduction of SM, no statistic significant difference between Group A (Theracal) and Group $\mathrm{B}$ (Biner LC) groups where $(p=0.723)$.

TABLE (3): The mean, standard deviation (SD) values of LOG 10 of S.mutans Bacterial count of different groups

\begin{tabular}{cccccc}
\hline & \multicolumn{4}{c}{ Streptococcus mutants viable count CFU/ml } \\
\cline { 2 - 5 } Variables & $\begin{array}{c}\text { Group A } \\
\text { (Theracal) }\end{array}$ & \multicolumn{2}{c}{$\begin{array}{c}\text { Group B } \\
\text { (Biner LC) }\end{array}$} & p-value \\
\cline { 2 - 5 } & Mean & SD & Mean & SD & \\
\hline Baseline & 4.52 & 0.10 & 4.49 & 0.09 & $0.282 \uparrow(\mathrm{NS})$ \\
After 6m & 2.85 & 0.93 & 2.99 & 0.24 & $0.474 \uparrow(\mathrm{NS})$ \\
\hline p-value & $<0.001 *$ & \multicolumn{2}{c}{$<0.001 *$} \\
\hline
\end{tabular}

*; significant $(p<0.05)$ ns; non-significant $(p>0.05)$

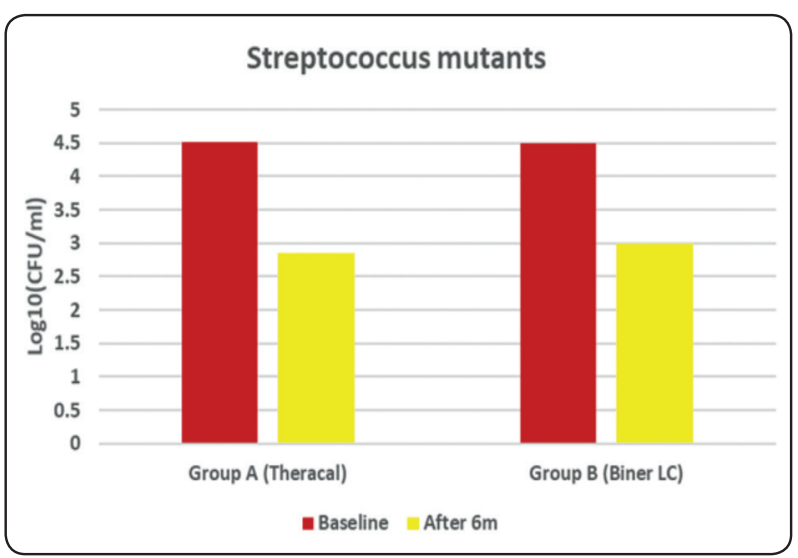

Fig. (1): Bar chart representing antibacterial activity (S.mutans) in each group.

\section{The anti-bacterial effect of capping material on Lactobacilli (LB)}

The effect of capping material on Lactobacilli (LB) was presented in the form of mean and standard deviation in (Table 4) and (Figure 2). There was a statistically significant difference between baseline (T1) and after 6months (T2) in both Theracal and Biner LC groups where $(\mathrm{p}<0.001)$. Between the two groups, bacterial count after 6 months (T2) shown in (Figure 2) presented no statistically significant difference between Group A(Theracal) and Group $\mathrm{B}$ (Biner LC) groups where $(p=0.799)$. Regarding bacterial reduction of LB presented in (Table $6 \&$ Figure 6) no statistic significant difference between Group A (Theracal) and Group B (Biner LC) where $(p=0.734)$.

TABLE (4): The mean, standard deviation (SD) values of LOG 10 of $L B$ Bacterial count of different groups.

\begin{tabular}{cccccc}
\hline & \multicolumn{4}{c}{ Lactobacillus viable count CFU/ml } \\
\cline { 2 - 5 } Variables & $\begin{array}{c}\text { Group A } \\
\text { (Theracal) }\end{array}$ & \multicolumn{2}{c}{$\begin{array}{c}\text { Group B } \\
\text { (Biner LC) }\end{array}$} & p-value \\
\cline { 2 - 5 } & Mean & SD & Mean & SD & \\
\hline Baseline & 4.19 & 0.21 & 4.22 & 0.17 & $0.561 \mathrm{~ns}$ \\
After 6m & 2.63 & 1.10 & 2.54 & 1.27 & $0.799 \mathrm{~ns}$ \\
\hline$p$-volue & \multicolumn{4}{c}{$<0.001 *$} & $<0.001 *$ \\
\hline
\end{tabular}

*; significant $(p<0.05)$ ns; non-significant $(p>0.05)$

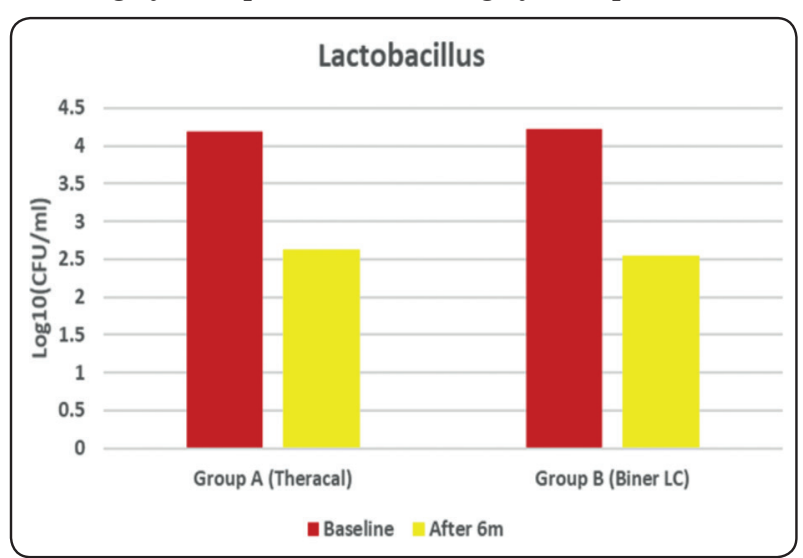

Fig. (2): Bar chart representing antibacterial activity $(L B)$ in each group. 


\section{DISCUSSION}

The "Two-Step" technique has been one of the approaches for pulp and dental tissue preservation also considered the preferable technique for microbiological studies to determine the bacteria persisting in clinically excavated lesions. ${ }^{[9]}$ First step of step-wise excavation consists of the removal of the central, cariogenic biomass together with the superficial parts of the necrotic and demineralized dentine at the first visit. Soft dentine and carious enamel in the peripheral parts of the cavity should be excised with rotating instruments. The excavation is finally completed to an decent clinical level in the peripheral dentine surrounding the central part. A base material must be applied, and a temporary seal of appropriate material put in place. After time interval of 6 month, second step consist of the removal of temporary restoration, the retained carious dentine is excavated, followed by the placing of the permanent restoration. ${ }^{[10]}$ It was stated by Oz, F. D., et al. (2019) that step-wise excavation should be considered for pulp preservation of deep dentin lesions compared to complete removal treatment after a 5 year clinical follow-up. ${ }^{[11]}$ Since the technique provides an adequate time for pulpdentine complex reactions to take place, therefore decreases the chance for a pulp exposure to occur in the second visit. ${ }^{[12]}$ Another factor put into account is the ability to promote the reduction of bacterial count by arresting caries progression. ${ }^{[13]}$ Re-entry of the cavity after an interval of 6-12 months was considered not critical ${ }^{[14]}$, after the process of sealing caries into the tooth, carious dentine becomes dry, harder and darker in colour. ${ }^{[9]}$ Inspecting the dentin condition and cavity floor may be in interest since the sealing process can cause shrinkage of the tissue leaving a void beneath the restoration. This factor supported the second stage in step-wise excavation. ${ }^{[12]}$

The approach of the two-step partial caries removal in the past years provided some benefits, however there are some limitations in this approach when compared to the single step partial caries removal. The drop-out of the patients tend to failure the performance of the step-wise technique, although they may have the same effect as partial caries removal, since this drop-out may lead to the failure of the temporary filling followed by the injury of the pulp. ${ }^{[4]}$ Additionally, stepwise excavations is associated with the possibility that the patient may abort to complete the final step of treatment for patients with limited financial resources due to higher costs or the dilemma with access to care which may lead to discomfort of the patient to this treatment. $^{[15]}$

The purpose of the stepwise excavation is to have some degree of remineralization as the form of reparative dentin and dentin bridging, occurred during the time interval between the first and second visits which will allow for remaining caries removal during the second visit to be without exposing the pulp. A Previous study showed that the Step-wise excavation group had a significant high proportion of success $(74.1 \%)$ at 1 year follow up in comparison to the complete excavation group $(62.4 \%)$, considering unexposed pulps with uninterrupted vitality with no apical pathology. ${ }^{[16]}$ On the other hand, there is a lack of evidenced-based systematic reviews regarding the best carious removal for permanent teeth whether partial, stepwise or complete. Many published reviews where more focused on the deciduous teeth, therefore further studies are necessary for scientific evidence concerning partial caries treatments of permanent tooth.

Barros et al., 2019 systematically reviewed the literature regarding the risk of partial removal in comparison with stepwise and complete removal of carious tissue in permanent teeth. The Systemic review concluded that the partial removal resulted in greater success of maintaining pulp vitality compared with both stepwise excavation and complete removal. Secondary outcomes, such as 
microbiological evaluation, restoration quality, and dentin deposition, also presented similar results among treatments. ${ }^{[17]}$

Light-cured calcium hydroxide where addressed to set the limitations of the chemical cure calcium hydroxide as which they set on command, originally no solubility in acid, minimal solubility in water with improvement of strength. A visible light-cured Calcium Hydroxide liner basically consists of calcium hydroxide and barium sulfate "dispersed in a urethane dimethacrylate resin containing initiators and accelerators activated by visible light". ${ }^{[18]}$ An article was made reviewing studies concerning the aim of introducing a better acquaintance of the role of Calcium Hydroxide as a cavity liner, the review concluded that light-cured calcium hydroxide liners are equally effective as standard chemical curing pulp capping liners in inhibiting the growth of organisms existing in a floor of a cavity preparation. ${ }^{[19]}$

Calcium hydroxide-based and calcium oxide $(\mathrm{CaO})$-based materials are the most prevalent agents for direct and indirect pulp capping, given their capacity to release hydroxyl $(\mathrm{OH})$ and calcium (Ca) ions upon dissolution, however the solubility level is not in favor. For this reason, a new era of calcium-releasing capping material was introduced to compensate for this matter ${ }^{[20]}$ TheraCal LC® (Bisco Inc, Schamburg, IL, USA) was introduced in the 2000's into dental purchases. The company markets this product as a "light-cured resin- modified calcium silicate" (RMCS) developed to be used as a liner for both direct and indirect pulp capping treatments. TheraCal consists of approximately $45 \%$ by weight "MTA (type III Portland cement), calcium oxide, barium zirconate (for radiopacity), photoinitiators, fumed silica (thickening agent), strontium glass, bisphenol A-glycidyl methacrylate (bis-GMA), and polyethylene glycol dimethacrylate (PEGDMA, hydrophilic monomer)". ${ }^{[1]}$ It has been suggested that the $\mathrm{Ca}$ and $\mathrm{OH}$ ion release within the wet surgical site (on the tooth pulp and/or dentine) is promoted and sustained due to the resin portion of TheraCal (comprising hydrophobic and hydrophilic monomers), and could favor the interaction of the formulation with the hydrophilic tooth dentine. ${ }^{[22]}$ TheraCal is incremented in a $1 \mathrm{~mm}$ layer and light-cured for 20 seconds. When light-cured, polymerization of the resin components of resin modified calcium silicate form a polymer matrix trapping the MTA, so the presence of the resin matrix customizes the setting mechanism and ion leaching abilities and characteristics of the MTA in resin modified calcium silicate. The hydraulic setting reactions and ion releasing abilities of MTA will need the presence of water, but there is no water imbedded in resin modified calcium silicate formulation so the water must come from another source. Application of resin modified calcium silicate on "visibly moist" dentin assisted in the initial setting reaction of the MTA due to this water source. ${ }^{[20]}$

In this current study, the antibacterial activity of indirect pulp capping materials after six months was obtained. Both groups displayed a significant reduction of the aciduric bacteria (Mutans Streptococci and Lactobacillus). This finding may be due to the decrease of the carious lesion activity and the restored microenvironment was lower in acidity as compared to carious tissue environment. Studies conducted by (Lula et al., 2009) and (Singhal et al., 2016) agreed on this finding. ${ }^{[5,23]}$ The possible explanation for the reduction in microbial count could be due to the blockage of the exogenous nutrients, creating a selective surrounding for microorganisms during which solely those most able to adapt can survive. The shortage of external nutrients offered to the microbiota growth is the most obvious environmental challenge for the residued microorganisms referred as "Nutritional starvation". [24] Or also due to the cavity capping with calcium hydroxide or calcium silicate which has bactericidal and bacteriostatic properties have 
drastically reduced the presence of cariogenic bacteria. $^{[25]}$

Regarding the results between the two pulp capping materials in the present study, there was no statistically significant difference between (Group A) and (Group B) in the microbial count (Streptococci Mutans and Lactobacillus) after 6 months. It does not seem that the antibacterial property is the only factor that can influence this effect but also the sealing properties are in account. This explanation are in line with other studies showed that good sealing with good adhesion to the dental tissues physically prevent penetration of bacteria towards the pulp and it is an important prerequisite for the success of indirect pulp capping treatment. ${ }^{[1,26]}$ In addition to the external "nutritional starvation", there is also the reduction of dentin permeability due to sclerosis formed. ${ }^{[24]}$ Bacteria such as Streptococci $\mathrm{Mu}$ tans is known as an important bacteria in forming biofilm and start dentin destruction and can grow only in a $\mathrm{pH}$ between 3 and $8 .{ }^{[27]}$ The high $\mathrm{pH}$ of calcium hydroxide (approximately 10) and resin modified calcium silicate (11-12) causes damage to organelles and cellular lysis, and the low $\mathrm{pH}$ of resin-modified glass ionomer during the initial setting (approximately 4) affects the production of adenosine triphosphate (ATP) and causes "structural damage" to the bacterial membrane because of the presence of the hydrogen ions which causes bactericidal effect on the remaining microorganisms. ${ }^{[28]}$ Additionally, the results of the present study were agreed with other two In- vivo studies. The first study was by (Gurcan \& Seymen, 2019) evaluated the radiographic and clinical events of TheraCal LC and to compare it with mineral trioxide aggregate (MTA) and calcium hydroxide $[\mathrm{Ca}(\mathrm{OH}) 2]$ (Dycal) biomaterials in Indirect pulp capping treatment in a 24 months follow-up. The conclusion was that there were no statistically significant differences between the materials. ${ }^{[29]}$ The second study (Bayoumy et al., 2020) evaluated the clinical and microbiological performances of Calcium silicate against Calcium hydroxide in two-step indirect pulp treatment after 6 and 12 month follow-up. Study achieved that Resin-modified calcium silicate and calcium hydroxide can both be considered as effective pulp capping materials through relieving pain and possessing antibacterial properties. ${ }^{[30]}$

Results of the current study was contradicted by (Gandolfi et al., 2014) in an in-vitro study declared that resin modified calcium silicate demonstrated higher calcium releasing ability and lower solubility than calcium hydroxide and the fast formation of apatite represent epigenetic signals for pulp cells and may clarify the role and function of calcium silicate biomaterials as scaffolds to generate the formation of new reparative tissue (dentin bridge) and healing clinically. ${ }^{[22]}$ In addition to (Gandolfi et al., 2012) which stated in an in-vitro study that the ability of TheraCal to be light-cured to a depth of $1.7 \mathrm{~mm}$ might avoid the risk of untimely dissolution. These properties offer major privileges in direct pulp-capping treatments. ${ }^{[20]}$

The results of the study have proven that pulp capping material is not solely the main reason of the success of indirect pulp technique, yet the success is dependant mainly on important factors, such as applying the indirect pulp treatment with caution, avoiding bacterial contamination, and to seal the teeth with a hermetic airtight restoration. For understanding the clinical efficiency of these materials more clinical studies with longer followup time intervals are essential.

\section{CONCLUSIONS}

Under the limitations of the current investigation, the following Conclusions were evident:

1. Antibacterial activity of the resin-modified calcium silicate has nearly the same effect as the light-cured Calcium Hydroxide, however still doubtful to be used as the gold standard for pulp capping material. 
2. Regardless the pulp capping material used, avoiding bacterial contamination and marginal sealing is essential in preserving the tooth vitality with deep Class I carious lesions.

\section{REFERENCES}

1. Pereira, M.A., dos Santos-Júnior, R.B., Tavares, J.A., Oliveira,A.H.,Leal,P.C., Takeshita,W.M.,Barbosa-Júnior, A.M., Bertassoni, L.E.B. and Faria-e-Silva, A.L., (2017): No additional benefit of using a calcium hydroxide liner during stepwise caries removal: a randomized clinical trial. The Journal of the American Dental Association, 148(6), pp.369-376. https://doi.org/10.1016/j.adaj.2017.02.019

2. Domejean, S., Ducamp, R., Léger, S., \& Holmgren, C. (2015): Resin infiltration of non-cavitated caries lesions: A systematic review. Medical Principles and Practice, 24(3), 216-221. https://doi.org/10.1159/000371709

3. Maltz, M., Garcia, R., Jardim, J.J., De Paula, L.M., Yamaguti, P.M., Moura, M.S., Garcia, F., Nascimento, C., Oliveira, A. and Mestrinho, H.D., (2012): Randomized trial of partial vs. stepwise caries removal: 3-year followup. Journal of dental research, 91(11),pp.1026-1031. https://doi.org/10.1177/0022034512460403

4. Maltz, M., Jardim, J. J., Mestrinho, H. D., Yamaguti, P. M., Podestá, K., Moura, M. S., \& De Paula, L. M. (2013): Partial removal of carious dentine: A multicenter randomized controlled trial and 18-month follow-up results. Caries Research, 47(2), 103-109. https://doi. org/10.1159/000344013

5. Singhal, D.K., Acharya, S. and Thakur, A.S., (2016): Microbiological analysis after complete or partial removal of carious dentin using two different techniques in primary teeth: A randomized clinical trial. Dental research journal, 13(1), p.30.

6. Poggio, C.,Arciola, C.R., Beltrami, R., Monaco,A., Dagna, A., Lombardini, M. and Visai, L., 2014. Cytocompatibility and antibacterial properties of capping materials. The Scientific World Journal, 2014.

7. Petrou, M.A., Alhamoui, F.A., Welk, A., Altarabulsi, M.B., Alkilzy, M. and Splieth, C.H., (2014): A randomized clinical trial on the use of medical Portland cement, MTA and calcium hydroxide in indirect pulp treatment. Clinical oral investigations, 18(5), pp.1383-1389. https://doi. org/10.1007/s00784-013-1107-z
8. Safwat, Osama, Mona Elkateb, Karin Dowidar, Hala Abdel Salam, and Omar El Meligy. (2017). "Microbiological Evaluation of Ozone on Dentinal Lesions in Young Permanent Molars Using the Stepwise Excavation." Journal of Clinical Pediatric Dentistry 42 (1): 11-20. https://doi.org/10.17796/1053-4628-42.1.3

9. Bjørndal,L.,Larsen, T. and Thylstrup,A. (1997): A Clinical and Microbiological Study of Deep Carious Lesions during Stepwise Excavation Using Long Treatment Intervals. Caries research, 31(6), pp.411-417.

10. Bjørndal, L. and Thylstrup, A., (1998): A practice-based study on stepwise excavation of deep carious lesions in permanent teeth: a 1-year follow-up study. Community Dentistry and Oral Epidemiology, 26(2), pp.122-128.

11. Oz, F.D., Bolay, S., Bayazit, E.O., Bicer, C.O. and Isikhan, S.Y., (2019). Long-term survival of different deep dentin caries treatments: A 5-year clinical study. Nigerian journal of clinical practice, 22(1).

12. Ricketts, D., (2001): Management of the deep carious lesion and the vital pulp dentine complex. British dental journal, 191(11), pp.606-610.

13. Larsen, L Bjørndal T. (2000). "Changes in the Cultivable Flora in Deep Carious Lesions Following a Stepwise Excavation Procedure." Caries Research, 502-8.https:// doi.org/10.1159/000016631.

14. Mertz-Fairhurst, E.J., Curtis Jr, J.W., Ergle, J.W., Rueggeberg, F.A. and Adair, S.M., (1998): Ultraconservative and cariostatic sealed restorations: results at year 10. The Journal of the American Dental Association, 129(1), pp.55-66.

15. Schwendicke, F., Stolpe, M., Meyer-Lueckel, H., Paris, S. and Dörfer, C.E., (2013): Cost-effectiveness of oneand two-step incomplete and complete excavations. Journal of dental research,92(10),pp.880-887. https://doi. org/10.1177/0022034513500792.

16. Bjørndal, L., Reit, C., Bruun, G., Markvart, M., Kjældgaard, M., Näsman, P., Thordrup, M., Dige, I., Nyvad, B., Fransson, H. and Lager, A., (2010): Treatment of deep caries lesions in adults: randomized clinical trials comparing stepwise vs. direct complete excavation, and direct pulp capping vs. partial pulpotomy. European journal of oral sciences, 118(3), pp.290-297.

17. Barros, Myrna Maria Arcanjo Frota, Maria Imaculada De Queiroz Rodrigues, Francisco Wilker Mustafa Gomes Muniz, and Lidiany Karla Azevedo Rodrigues. (2019). "Selective, Stepwise, or Nonselective Removal of Carious 
Tissue: Which Technique Offers Lower Risk for the Treatment of Dental Caries in Permanent Teeth? A Systematic Review and Meta-Analysis.” Clinical Oral Investigations. https://doi.org/10.1007/s00784-019-03114-5.

18. Salzmann, J. A. (1977): Restorative dental materials. American Journal of Orthodontics, 71(2), 228. https://doi. org/10.1016/s0002-9416(77)90403-1.

19. Arandi, Naji Ziad. (2017): Calcium hydroxide liners: A literature review. Clinical, Cosmetic and Investigational Dentistry, Vol 9, 67-72.https:// doi.org/10. 2147/ CCIDE. S141381.

20. Gandolfi, M.G., Siboni, F. and Prati, C., (2012). Chemicalphysical properties of TheraCal, a novel light-curable MTA-like material for pulp capping. International Endodontic Journal, 45(6), pp.571-579. https://doi. org/10.1111/j.1365-2591.2012.02013.x.

21. Suh, B., Brook, O., Yin, R., \& Grove, B. (2008): (12) Patent Application Publication (10) Pub. No.: US 2008/0318190 A1, 1(19).

22. Gandolfi, Maria Giovanna, Siboni, F., Botero, T., Bossù, M., Riccitiello, F., \& Prati, C. (2014): Calcium silicate and calcium hydroxide materials for pulp capping: biointeractivity, porosity, solubility and bioactivity of current formulations. Journal of applied biomaterials \& functionalmaterials,13(1), pp.43-60. https://doi.org/10.5301/ jabfm.5000201.

23. Lula, E. C. O., Monteiro-Neto, V., Alves, C. M. C., \& Ribeiro, C. C. C. (2009): Microbiological analysis after complete or partial removal of carious dentin in primary teeth: A randomized clinical trial. Caries Research, 43(5), 354-358. https://doi.org/10.1159/000231572.
24. Paddick, J.S., Brailsford, S.R., Kidd, E.A.M. and Beighton, D., 2005. Phenotypic and genotypic selection of microbiota surviving under dental restorations. Applied and environmental microbiology, 71(5), pp.2467-2472. https://doi.org/ 10.1128/ AEM. 71.5.2467.

25. Bowden, G.H. and Hamilton, I.R., (1998): Survival of oral bacteria. Critical Reviews in Oral Biology \& Medicine, 9(1), pp.54-85.

26. Radman, I. K., Djeri, A., Arbutina, A., \& Milašin, J. (2016). Microbiological Findings in Deep Caries Lesions, Stomatološki glasnik Srbije, 63(1), pp.7-14. https://doi. org/10.1515/sdj-2016-0001.

27. Maltz, M., E. F. Oliveira, V. Fontanella, and G. Carminatti. (2007). "Deep Caries Lesions after Incomplete Dentine Caries Removal: 40-Month Follow-up Study."Caries Research 41 (6): 493-96. https://doi.org/10.1159/000109349.

28. Cotter, P.D. and Hill, C., (2003): Surviving the acid test: responses of gram-positive bacteria to low $\mathrm{pH}$. Microbiology and molecular biology reviews,67(3),pp.429-453. https:// doi.org/10.1128/MMBR.67.3.429.

29. Gurcan, A.T. and Seymen, F., (2019): Clinical and radiographic evaluation of indirect pulp capping with three different materials: a 2-year follow-up study. European journal of paediatric dentistry, 20(2), pp.105-110. https:// doi.org/ 10.23804/ ejpd.2019.20.02.04.

30. Bayoumy, E. H. E., Hussien, M., Elhassan, A., Al-zohairy, A. A. F., \& Al-awady, B. A. (2020): Clinical and microbiological evaluation of calcium silicate versus calcium hydroxide in two-step indirect pulp treatment: A randomized clinical trial. Journal of International Oral Health 13.1 : 1. https://doi.org/10.4103/jioh.jioh. 